\title{
Application of Hydrodynamic Cavitation for Improving Methane Fermentation of Sida hermaphrodita Silage
}

\author{
Marcin Zieliński ${ }^{1}$, Paulina Rusanowska ${ }^{1, * \mathbb{C}}$, Aleksandra Krzywik ${ }^{2}$, Magda Dudek ${ }^{1} \mathbb{D}$, \\ Anna Nowicka ${ }^{1}$ (D) and Marcin Dębowski ${ }^{1}$ (D) \\ 1 University of Warmia and Mazury in Olsztyn, Department of Environment Engineering, Warszawska 117, \\ 10-720 Olsztyn, Poland; marcin.zielinski@uwm.edu.pl (M.Z.); magda.dudek@uwm.edu.pl (M.D.); \\ anna.grala@uwm.edu.pl (A.N.); marcin.debowski@uwm.edu.pl (M.D.) \\ 2 Czestochowa University of Technology, J.H. Dabrowskiego 69, 42-201 Częstochowa, Poland; euroola@wp.pl \\ * Correspondence: paulina.jaranowska@uwm.edu.pl
}

Received: 3 January 2019; Accepted: 3 February 2019; Published: 7 February 2019

check for updates

\begin{abstract}
Hydrodynamic cavitation was recently applied as a biomass pretreatment method. Most of the studies which used hydrodynamic cavitation were applied to pretreated sugarcane bagasse or reed. High biomass yield of Sida hermaphrodita points out the necessity of studies on its effective pretreatment before methane fermentation, especially because its "wood-like" characteristics could present different disintegration properties than other lignocellulose biomass. Thus, the aim of the study was to investigate the influence of duration of hydrodynamic cavitation on lignocellulose composition in Sida hermaphrodita silage, and the assessment of disintegrated biomass as a substrate for methane fermentation. The study showed a slight decrease in lignin, cellulose, and hemicellulose content in biomass after hydrodynamic cavitation, which resulted in a higher content of carbohydrates in the liquid fraction of disintegrated substrates. Methane production was $439.1 \pm 45.0 \mathrm{~L} \mathrm{CH}_{4} / \mathrm{kg}_{\text {total }}$ solids (TS) from the substrate disintegrated for $20 \mathrm{~min}$. However, the most effective time for methane production was hydrodynamic cavitation of the substrate for $5 \mathrm{~min}$. At this pretreatment duration, the highest values for chemical oxygen demand (COD), total organic carbon (TOC), and carbohydrate reduction were also noted. The study proved that hydrodynamic cavitation applied for 5 min allowed obtaining an energy profit of $0.17 \mathrm{Wh} / \mathrm{g}$ TS. The studies on a laboratory scale indicated that the technology of hydrodynamic cavitation of Sida hermaphrodita could be economically applied for methane fermentation on a large scale.
\end{abstract}

Keywords: Virginia mallow; Virginia fanpetals; hydrodynamic cavitation; biogas production

\section{Introduction}

Lignocellulose biomass, including agriculture and forestry waste, municipal solid waste, and herbaceous energy crops, is considered as a beneficial substrate used in biogas plants [1]. The structure of lignocellulose consists of cellulose, the skeleton of which is surrounded by hemicellulose and lignin. The effective decomposition of lignocellulose biomass should be preceded by conversions of these polysaccharides into monosaccharides. However, cellulose and hemicellulose are tightly bound mainly by hydrogen bonds to the lignin, which is the most recalcitrant component that hinders degradation of carbohydrate polymers. Additional properties of lignocellulose biomass, including the crystallinity of cellulose, its accessible surface area, the degree of cellulose polymerization, and the degree of acetylation of hemicelluloses, also inhibit its decomposition [2]. Thus, an efficient pretreatment method, which can release carbohydrates and break them down to fermentable monomers in an easy and cost-effective way, is needed. 
Pretreatment methods are divided into chemical, mechanical, thermal, and biological types [3]. Chemical methods use acidic and alkali compounds, or oxidants. Their function is to cleave the lignin-carbohydrate link and cellulose crystallinity, or to hydrolyze the hemicellulose. Mechanical methods include grinding, milling, or chipping. Their aim is to increase surface area available for anaerobic bacteria through a disintegration of biomass into small particles. During thermal methods, a wide range of temperatures $\left(50-250^{\circ} \mathrm{C}\right)$ are applied. In biological methods, commercial enzymes are used to break down the lignocellulosic components. These pretreatment methods require high energy or chemical input, while inhibitory by-products could also be created. Biological pretreatment is not subjected to these drawbacks; however, the high price of enzymes that are required in large doses reduces the possibility of using them in biogas plants.

Recently, hydrodynamic cavitation was applied as a non-conventional pretreatment method and provided valuable results. The potential of hydrodynamic cavitation was proven for the pretreatment of sugarcane bagasse, corn stover, and reed with the use of laboratory equipment, as well as for the pretreatment of pig slurry, energy crops, and agricultural by-products in full-scale biogas plants. Hydrodynamic cavitation is based on the formation, growing, and collapse of micro-bubbles generated by a drop in pressure of the liquid flowing through the cavitating device. This collapse of the cavities releases a very high amount of energy that causes water molecules to dissociate into radicals of hydroxyl and hydrogen $(\mathrm{OH}$ and $\mathrm{H} \cdot)$, which can contribute to lignin removal from biomass [4-6]. The authors of some studies performed hydrodynamic cavitation with the addition of sodium bicarbonate, calcium hydroxide, or sodium hydroxide in order to improve delignification [7-10]. However, it is not economically justifiable to add chemical compounds to biomass during its pretreatment in a biogas plant.

Hydrodynamic cavitation was mainly used for the removal of toxic substances and biomass disintegration before alcoholic fermentation. Only a few studies investigated the effect of cavitation of lignocellulose biomass on methane fermentation. Due to the varying composition of lignocellulose biomass, different plant species can be less or more susceptible to disintegration. Sida hermaphrodita, also known as Virginia mallow or Virginia fanpetals, was evaluated as a promising plant for bioenergy production due to its high yield and low nutrient demand [11-14] The high biomass yield of Sida hermaphrodita is a result of numerous shoots per plant and its wood-like characteristics, and it depends on environmental conditions, age of the plant, and the time of harvest $[15,16]$. Damm et al. [17] investigated the cell-wall structure of Sida hermaphrodita and observed that this plant lacks phenolic ester linkages between lignin and carbohydrates. Thus, the authors suggested that methods other than those used for common bioenergy crops such as switchgrass or Miscanthus could be applied for the disintegration of Sida hermaphrodita biomass.

This study aimed to investigate the influence of the hydrodynamic cavitation on lignocellulose biomass composition of Sida hermaphrodita. The effect of the disintegration duration on lignin, hemicellulose, and cellulose content in biomass and the dissolved carbohydrate content was examined. Disintegrated biomass was used for an assessment of the methane potential.

\section{Materials and Methods}

\subsection{Substrate}

The substrate used in the study was Sida hermaphrodita silage, which was mixed with cattle manure in order to increase its moisture to $96 \%$. The volatile solids (VS) in the substrate constituted $93.2 \pm$ $2.4 \%$ of total solids (TS), and ash constituted $6.8 \pm 1.3 \%$ of TS. The average value of total carbon (TC) was $0.413 \mathrm{~g} / \mathrm{g} \mathrm{TS}$, and that of total organic carbon (TOC) was $0.382 \mathrm{~g} / \mathrm{g}$ TS, while that of total nitrogen (TN) was $0.005 \mathrm{~g} / \mathrm{g}$ TS. 


\subsection{Equipment}

Hydrodynamic cavitation was carried out in a mechanical disintegrator, which consisted of a multifunction rotor that was made according to patent PL 214335 B1 (Figure 1). The rotor was driven by an electric motor with a power of $4 \mathrm{KW}$ at $2800 \mathrm{rpm}$. The capacity of the tank was $25 \mathrm{~L}$. The inlet was located on the bottom of the tank, whereas the outlet was on the cover of the tank. The inlet and outlet were equipped with two-inch valves that were connected to each other in order to allow for the flow of liquids, excluding flow through the tank. The tank had additional half-inch connectors, equipped with a thermometer, a manometer, and a sampling valve.

A

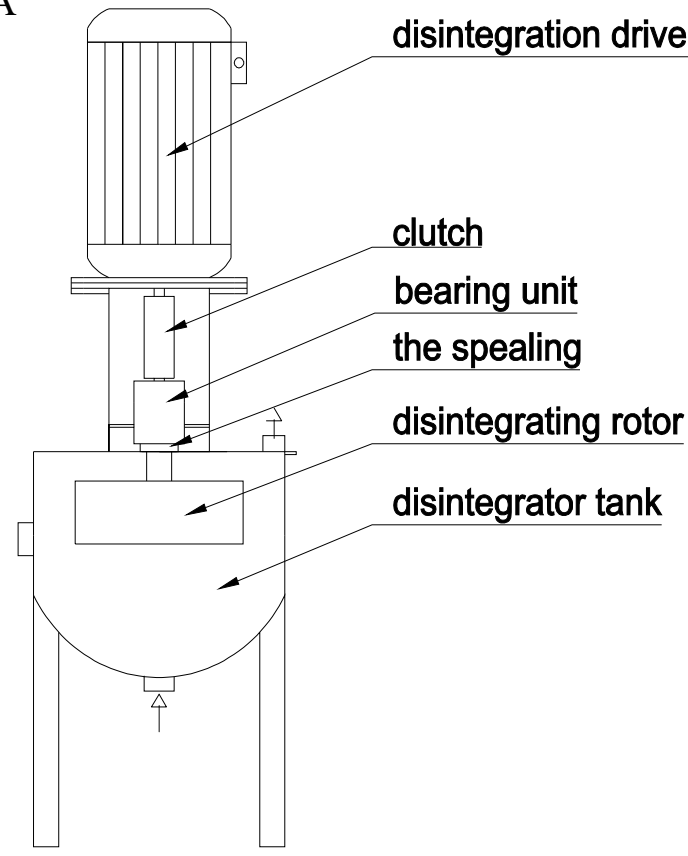

B
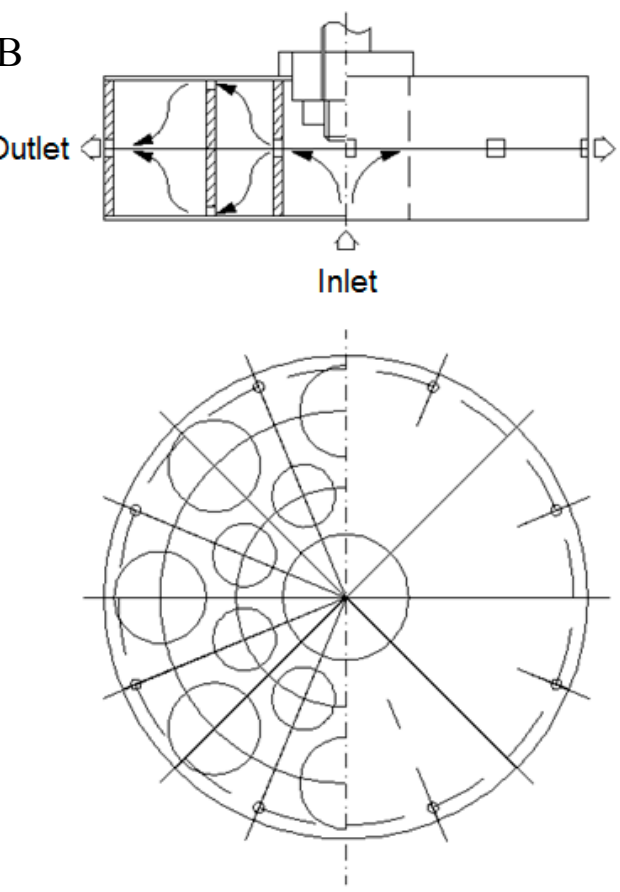

Figure 1. The scheme of the hydrodynamic cavitator (A) and cavitation head (B).

\subsection{Cavitation}

The substrate was pumped many times through the rotor due to the centrifugal force; it was sucked inside through the inlet located in the axis of the rotor, and then flowed to the outer edge; afterward, it was thrown outside the rotor. Flowing inside the rotor through subsequent channels and the chamber, the substrate was subjected alternately to low and high pressure, which created conditions for the formation and disappearance of cavitation bubbles destroying the lignocellulosic structure of the substrate.

The study investigated the effect of the duration of hydrodynamic cavitation on biogas production; for this purpose, the substrate was introduced to the cavitator for 2.5, 5, 10, 15, and $20 \mathrm{~min}$. After pretreatment, the substrate was subjected to physico-chemical analyses and methane potential analysis in AMPTS II (Bioprocess Control).

\subsection{Determination of Cellulose, Hemicellulose, and Lignin}

The procedure proposed by van Soest et al. [18] was used to examine the cellulose-like, hemicellulose-like, and lignin-like content of the raw substrate and disintegrated substrate through chemical fractionation with the following detergents: neutral detergent (NDF), acid detergent fiber (ADF), and acid detergent lignin (ADL). Cellulose was estimated as the difference between ADF and $\mathrm{ADL}$, and hemicellulose was estimated as the difference between NDF and ADF. 


\subsection{Analytical Methods}

In the liquid, obtained after the centrifugation of raw and disintegrated substrate, glucose and carbohydrate levels were determined. In the samples introduced to AMPTS II and in the samples after fermentation, the $\mathrm{pH}$, the FOS/TAC ratio (explained below), the TS and volatile solids (VS), the glucose and carbohydrate levels, and the TOC and total TN were determined. AMPTS II was used to measure the quantity of methane produced. Methane fermentation was performed in reactors with a capacity of $500 \mathrm{~mL}$. The reactors were equipped with the multifunctional agitation system, which ran for 30 seconds every $10 \mathrm{~min}$ at a speed of $100 \mathrm{rpm}$. Anaerobic sludge from a fractional-scale reactor with a cage mixing system was used as an inoculum, and $200 \mathrm{~mL}$ of the inoculum was introduced to the reactors. The organic compound was loaded at $5 \mathrm{~g} / \mathrm{dm}^{3}$. Flushing of pure nitrogen through the sludge created anaerobic conditions. The reactors were kept in the water batch at $37^{\circ} \mathrm{C}$ for 40 days. The experiments were performed in triplicate. The composition of biogas was measured using a gas chromatograph connected to a thermal conductivity detector (GC-TCD) (Agillent $7890 \mathrm{~A}$ ). The FOS/TAC ratio, which is the ratio of buffer capacity of the sample and volatile fatty acid content in the sample, was determined with a TitraLab AT1000 Series Titrator (Hatch). The TS and VS in the biomass were measured using gravimetric methods. The glucose was determined on a YSI 2700 Select Biochemistry Analyzer (Marshall Scientific) and the carbohydrates were measured using the Anthron method with a glucose standard curve. The concentrations of TN and TOC were measured using TOC-L (Schimatzu). The quality of biomass (carbon and nitrogen content) was tested using Thermo 2000 (USA). The homogeneity of variance was tested with Levene's test. and the significance of differences between variants was tested with Tukey's honestly significant difference (HSD) test. Differences were considered significant at $p<0.05$.

\section{Results and Discussion}

\subsection{Pretreatment Efficiency}

Hydrodynamic cavitation increased the temperature of the substrate by $20{ }^{\circ} \mathrm{C}$ after 20 min of pretreatment. This increase corresponds to values previously reported during the treatment of toxic compounds $[19,20]$ and disintegration of sugarcane bagasse [8]. Some of the studies controlled the temperature of pretreatment with a water jacket or ice placed around the cavitator. Terán Hilares et al. [6] reported that disintegration was improved when the temperature was increased to $45^{\circ} \mathrm{C}$. Higher temperatures could increase vapor pressure and generate vapor cavities, thereby decreasing the intensity of cavitation during collapse. In the present study, the temperature was increased to $30{ }^{\circ} \mathrm{C}$; therefore, it was not controlled.

The composition of the biomass is presented in Table 1. The obtained results of lignocellulose composition in Sida hermaphrodita are slightly different from those presented by other authors [21,22]. Krička et al. [22] reported that the contents of cellulose, hemicellulose, and lignin were about $40.1 \%$, $27.2 \%$, and $26.4 \%$, respectively. These differences resulted from the present study investigating the composition of the substrate (Sida hermaphrodita mixed with cattle manure). The studies mentioned above investigated the composition of only plant. Cattle manure could change the lignocellulose content, because it also possesses lignocellulose accounting for more than half the dry mass [23].

The duration of hydrodynamic cavitation slightly lowered the cellulose and lignin content in the biomass; however, the values noted after pretreatment were not statistically different (Table 1) $(p<0.05)$. The carbohydrate content in the liquid increased by $50 \mathrm{mg} / \mathrm{g}$ after $10 \mathrm{~min}$ of hydrodynamic cavitation. This increase resulted from the removal and disintegration of the hemicellulose from biomass, the structure of which is a mixture of fucose, rhamnose, arabinose, galactose, xylose, mannose, galactouronic acid, and glucouronic acid in Sida hermaphrodita [17]. The removal of hemicellulose from the biomass opened up the lignocellulosic matrix structure, which facilitated the breakdown of cellulose. An increase in the duration of pretreatment above $10 \mathrm{~min}$ did not significantly change the carbohydrate content. The elementary composition of the biomass did not change significantly during 
hydrodynamic cavitation $(p<0.05)$. In the control sample, carbon content in the biomass was $37.2 \pm$ $0.9 \% \mathrm{TS}$ and, in the sample pretreated for $20 \mathrm{~min}$, it was $38.9 \pm 1.8 \%$ TS. In all samples, the organic carbon content in the biomass was $70 \pm 2 \%$, and the total nitrogen in the biomass was $3.3 \pm 0.8 \%$ TS Madison et al. [10] reported that a long duration of hydrodynamic cavitation did not significantly change the crystallinity of sugarcane bagasse. The authors used pretreatment times ranging from 0 to 120 minutes, and controlled the temperature at $22{ }^{\circ} \mathrm{C}$ with $20 \mathrm{~kg}$ of ice placed around the cavitator. However, Kim et al. [7] used hydrodynamic cavitation to improve the alkaline pretreatment of reed. The authors observed a high digestibility yield of $85 \%$, which was higher than that observed in the untreated sample by about $70 \%$. The reasons for the differences in the results of the influence of hydrodynamic cavitation on biomass disintegration involve the equipment used, the parameters of pretreatment, and the structure of the lignocellulosic biomass. Most studies were based on an orifice plate [6,24]; however, a rotor-stator assembly was also used [20]. The different parameters included pressure at the inlet to the reactor/tank/cavitator, speed of rotation, and the presence of additives (sodium bicarbonate, calcium hydroxide, or sodium hydroxide). All of these factors could increase beyond certain values and induce super-cavitation, which would not collapse the cavities and, thus, not destroy the compounds/biomass [25].

Table 1. The composition of the substrate before and after pretreatment, and the amount of glucose and carbohydrate released to the liquid phase of the substrate. TS—-total solids.

\begin{tabular}{cccccc}
\hline $\begin{array}{c}\text { Duration of Hydrodynamic } \\
\text { Cavitation (min) }\end{array}$ & $\begin{array}{c}\text { Cellulose } \\
\text { (\% TS) }\end{array}$ & $\begin{array}{c}\text { Hemicellulose } \\
\text { (\% TS) }\end{array}$ & $\begin{array}{c}\text { Lignin } \\
\text { (\% TS) }\end{array}$ & $\begin{array}{c}\text { Glucose Yield } \\
\text { (mg/g TS) }\end{array}$ & $\begin{array}{c}\text { Carbohydrate } \\
\text { Yield (mg/g TS) }\end{array}$ \\
\hline 0 (control) & $32.8 \pm 3.5$ & $29.6 \pm 3.4$ & $19.7 \pm 1.3$ & $90.2 \pm 4.5$ & $310.3 \pm 9.7$ \\
2.5 & $31.9 \pm 2.9$ & $28.7 \pm 1.4$ & $19.5 \pm 1.2$ & $90.9 \pm 2.2$ & $324.9 \pm 11.8$ \\
5 & $31.6 \pm 3.4$ & $26.4 \pm 2.7$ & $19.3 \pm 1.5$ & $92.1 \pm 1.1$ & $346.8 \pm 19.1$ \\
10 & $30.5 \pm 2.1$ & $26.2 \pm 2.0$ & $19.4 \pm 2.1$ & $93.1 \pm 6.3$ & $365.5 \pm 10.1$ \\
15 & $30.1 \pm 2.2$ & $26.0 \pm 3.1$ & $18.5 \pm 1.5$ & $92.2 \pm 3.8$ & $366.8 \pm 12.3$ \\
20 & $29.5 \pm 3.9$ & $25.7 \pm 1.1$ & $18.0 \pm 0.9$ & $94.3 \pm 2.3$ & $368.9 \pm 14.5$ \\
\hline
\end{tabular}

\subsection{Methane Production}

The raw and the pretreated substrate with Sida hermaphrodita biomass were used for an evaluation of methane potential. After the methane fermentation, the FOS/TAC ratio did not significantly differ between experiments $(0.13 \pm 0.0$ to $0.14 \pm 0.0)$, suggesting a stable process $(p<0.05)$. The highest removal rates of TOC, chemical oxygen demand (COD), and carbohydrate were noted during the fermentation of the substrate disintegrated for $20 \mathrm{~min}$ (Table 2). However, the highest reduction in the level of organic compounds compared to the control sample was noted during methane fermentation of the substrate pretreated for $5 \mathrm{~min}$. Glucose was completely removed in all fermentation processes. After fermentation, the elementary composition of the biomass decreased to $34.8 \pm 1.2 \%$ TS in the control sample and to $31.7 \pm 1.1 \%$ TS in the sample pretreated for $20 \mathrm{~min}$. The organic carbon content in the biomass was about $70 \pm 2 \%$, while the nitrogen content in the biomass was about $3.3 \pm 0.8 \% \mathrm{TS}$ before fermentation and $3.4 \pm 0.5 \%$ TS after fermentation.

Table 2. The percentages of total organic content (TOC), chemical oxygen demand (COD), and carbohydrate removed.

\begin{tabular}{cccc}
\hline Experiment (min) & TOC Removed (\%) & COD Removed (\%) & Carbohydrate Removed (\%) \\
\hline 0 (control) & $60.2 \pm 5.4$ & $53.5 \pm 3.2$ & $49.1 \pm 7.2$ \\
2.5 & $68.1 \pm 2.3$ & $61.9 \pm 5.4$ & $53.2 \pm 8.1$ \\
5 & $79.3 \pm 3.7$ & $69.4 \pm 4.2$ & $59.2 \pm 7.9$ \\
10 & $79.4 \pm 2.1$ & $71.3 \pm 2.9$ & $59.4 \pm 6.3$ \\
15 & $80.4 \pm 2.5$ & $74.4 \pm 3.1$ & $60.1 \pm 9.2$ \\
20 & $84.1 \pm 3.2$ & $75.5 \pm 6.1$ & $63.2 \pm 8.8$ \\
\hline
\end{tabular}


The methane production noted in the control fermentation was about $340 \mathrm{~mL} \mathrm{CH}_{4} / \mathrm{g}$ VS. The study confirmed previous results, which showed the high potential of Sida hermaphrodita for methane production [26]. The methane potential of the control biomass was higher than that of maize (291-338 mL CH $/$ /g VS), tricale (319-335 mL CH 4 /g VS), sorghum (286-324 mL CH 4 /g VS), grass (286-324 mL CH $/$ /g VS), and sunflower (231-297 $\mathrm{mL} \mathrm{CH}_{4} / \mathrm{g} \mathrm{VS}$ ). The methane production from the pretreated biomass increased with an increase in pretreatment time up to 5 min (Figure 2). Pretreatment times longer than 5 min only slightly increased the methane generation. The methane content in the biogas did not significantly differ between experiments and ranged from $57.8 \pm 1.1 \%$ to $59.4 \pm 1.2 \%$. Nevertheless, the characteristics of the biomass after hydrodynamic cavitation did not show that the pretreatment method released cellulose and converted it to monomers that would be easy biodegradable; hydrodynamic cavitation probably increased the digestibility of the biomass, which resulted in a higher methane production from the disintegrated substrate than that observed in the control experiment. Patil et al. [27] used hydrodynamic cavitation as the pretreatment method of wheat straw for biogas production. The authors observed a higher methane production by about $144 \%$ from biomass cavitated for $2 \mathrm{~min}$; however, the overall methane production noted by the authors (about 50-77 $\mathrm{mL} \mathrm{CH}_{4} / \mathrm{g} \mathrm{TS}$, depending on the experiment) was lower than in the present study (about $390-440 \mathrm{~mL} \mathrm{CH}_{4} / \mathrm{g} \mathrm{VS}$, depending on the experiment). In another study, the mechanical pretreatment of Sida hermaphrodita increased the biogas production by $8 \%$ at an organic loading rate of $2 \mathrm{~kg} /\left(\mathrm{m}^{3} \cdot \mathrm{d}\right)$ and by $22 \%$ in the reactor operated at an organic loading rate of $3 \mathrm{~kg} /\left(\mathrm{m}^{3} \cdot \mathrm{d}\right)$ [28]. Microwave radiation used for the heating of the methane fermentation reactor increased the biogas production from Sida hermaphrodita silage by 18\% [29]. Hydrodynamic cavitation was more efficient than the abovementioned methods because it increased methane production by about $30 \%$ (for $5 \mathrm{~min}$ of pretreatment).

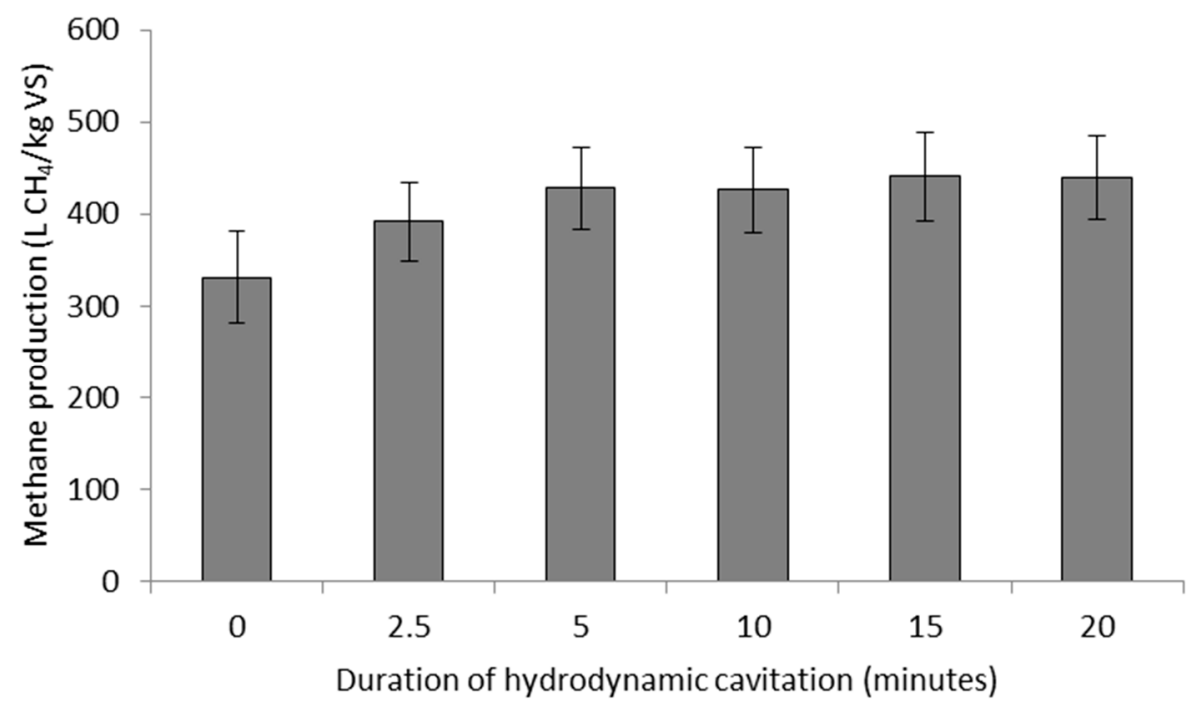

Figure 2. Methane production from the pretreated substrate with hydrodynamic cavitation.

Based on the obtained results, an energy calculation of the produced biogas was carried out (Table 3). The calorific value of the obtained biogas was used for a calculation of the increase in energy due to hydrodynamic cavitation. Then, to obtain the gain of energy, the value of the energy increase was subtracted from the value of the energy introduced. This analysis proved that hydrodynamic cavitation applied for $5 \mathrm{~min}$ allowed obtaining an energy profit of $0.17 \mathrm{Wh} / \mathrm{g}$ TS (Table 3). Methane production and energy profit from the pretreated substrate in a biogas plant would be different from the batch results presented in this study due to methane fermentation being influenced by organic loading rate and retention time. However, the obtained results are very promising and indicate that hydrodynamic cavitation could be introduced into technological systems in a biogas plant. 
Table 3. Calculation of the economic efficiency of the hydrodynamic cavitation of biomass.

\begin{tabular}{ccccc}
\hline Experiment (min) & $\begin{array}{c}\text { Energy Input } \\
\text { (Wh/g TS) }\end{array}$ & $\begin{array}{c}\text { Calorific Value of Produced } \\
\text { Biogas (Wh/g TS) }\end{array}$ & $\begin{array}{c}\text { Increase in Energy } \\
\text { Due to Cavitation }\end{array}$ & $\begin{array}{c}\text { Energy Profit } \\
\text { (Wh/g TS) }\end{array}$ \\
\hline 0 (control) & 0 & 1.52 & & 0.14 \\
2.5 & 0.14 & 1.80 & 0.28 & 0.17 \\
5 & 0.28 & 1.96 & 0.45 & -0.12 \\
10 & 0.56 & 1.96 & 0.44 & -0.33 \\
15 & 0.83 & 2.02 & 0.51 & -0.62 \\
\hline
\end{tabular}

\section{Conclusions}

These studies on a laboratory scale indicate that the technology of hydrodynamic cavitation could be economically applied on a bigger scale for the methane fermentation of Sida hermaphrodita silage. Hydrodynamic cavitation did not change the chemical composition of the lignocellulose biomass; however, it increased its digestibility, which was proven by the higher methane production from the substrate disintegrated for 5 min than that from the control sample.

Author Contributions: Conceptualization, M.Z. and M.D. (Marcin Dębowski); funding acquisition, M.Z.; investigation, P.R., A.K., M.D. (Magda Dudek) and A.N.; supervision, M.Z.; visualization, P.R.; writing一original draft, P.R.; writing—review and editing, M.Z., A.K., M.D. (Magda Dudek), A.N. and M.D. (Marcin Dębowski).

Funding: The study was carried out in the framework of the project "Dietary, power, and economic potential of Sida hermaphrodita cultivation on fallow land" under program BIOSTRATEG, funded by the National Center for Research and Development No. 1/270745/2/NCBR/2015.

Conflicts of Interest: The authors declare no conflict of interest.

\section{References}

1. Bhatia, S.K.; Kim, S.-H.; Yoon, J.-J.; Yang, Y.-H. Current status and strategies for second generation biofuel production using microbial systems. Energy Convers. Manag. 2017, 148, 1142-1156. [CrossRef]

2. Khanal, S.K.; Rasmussen, M.; Shrestha, P.; Van Leeuwen, H.; Visvanathan, C.; Liu, H. Bioenergy and biofuel production from wastes/residues of emerging biofuel industries. Water Environ. Res. 2008, 80, 1625-1647. [CrossRef]

3. Paudel, S.R.; Banjara, S.P.; Choi, O.K.; Park, K.Y.; Kim, Y.M.; Lee, J.W. Pretreatment of agricultural biomass for anaerobic digestion: Current state and challenges. Bioresour. Technol. 2017, 245, 1194-1205. [CrossRef] [PubMed]

4. Tang, H.; Wang, C.C.J.; Blankschtein, D.; Langer, R. An investigation of the role of cavitation in low-frequency ultrasound-mediated transdermal drug transport. Pharm. Res. 2002, 19, 1160-1169. [CrossRef] [PubMed]

5. Vanhille, C.; Campos-Pozuelo, C. Nonlinear ultrasonic standing waves: Two-dimensional simulations in bubbly liquids. Ultrason. Sonochem. 2011, 18, 679-682. [CrossRef] [PubMed]

6. Terán Hilares, R.; Ramos, L.; Da Silva, S.S.; Dragone, G.; Mussatto, S.I.; Dos Santos, J.C. Hydrodynamic cavitation as a strategy to enhance the efficiency of lignocellulosic biomass pretreatment. Crit. Rev. Biotechnol. 2018, 38, 483-493. [CrossRef] [PubMed]

7. Kim, I.; Lee, I.; Jeon, S.H.; Hwang, T.; Han, J.I. Hydrodynamic cavitation as a novel pretreatment approach for bioethanol production from reed. Bioresour. Technol. 2015, 192, 335-339. [CrossRef]

8. Terán Hilares, R.; Dos Santos, J.C.; Ahmed, M.A.; Jeon, S.H.; Silva, S.S.; Han, J.I. Hydrodynamic cavitation-assisted alkaline pretreatment as a new approach for sugarcane bagasse biorefineries. Bioresour. Technol. 2016, 214, 609-614. [CrossRef]

9. Nakashima, K.; Ebi, Y.; Shibasaki-Kitakawa, N.; Soyama, H.; Yonemoto, T. Hydrodynamic cavitation reactor for efficient pretreatment of lignocellulosic biomass. Ind. Eng. Chem. Res. 2016, 55, 1866-1871. [CrossRef]

10. Madison, M.J.; Coward-Kelly, G.; Liang, C.; Karim, M.N.; Falls, M.; Holtzapple, M.T. Mechanical pretreatment of biomass-Part I: Acoustic and hydrodynamic cavitation. Biomass Bioenergy 2016, 98, 500-508. [CrossRef]

11. Borkowska, H.; Wardzinska, K. Some effects of Sida hermaphrodita R. Cultivation on sewage sludge. Pol. J. Environ. Stud. 2003, 12, 111-122. 
12. Borkowska, H.; Molas, R. Two extremely different crops, Salix and Sida, as sources of renewable bioenergy. Biomass Bioenergy 2012, 36, 234-240. [CrossRef]

13. Barbosa, D.B.P.; Nabel, M.; Jablonowski, N.D. Biogas-digestate as nutrient source for biomass production of Sida hermaphrodita, Zea mays, L. and Medicago sativa L. Energy Procedia 2014, 59, 120-126. [CrossRef]

14. Nabel, M.; Bueno, D.; Barbosa, P.; Horsch, D.; Jablonowski, N.D. Energy crop (Sida hermaphrodita) fertilization using digestate under marginal soil conditions: A dose-response experiment. Energy Procedia 2014, 16, 127-133. [CrossRef]

15. Slepetys, J.; Kadziuliene, Z.; Sarunaite, L.; Tilvikiene, V.; Kryzeviciene, A. Biomass potential of plants grown for bioenergy production. Int. Sci. Conf. Renew. Energy Energy Effic. 2012, 12, 66-72.

16. Borkowska, H.; Molas, R. Yield comparison of four lignocellulosic perennial energy crop species. Biomass Bioenergy 2013, 51, 145-153. [CrossRef]

17. Damm, T.; Pattathil, S.; Günl, M.; Jablonowski, N.D.; O'neill, M.; Grün, K.S.; Grande, P.M.; Leitner, W.; Schurr, U.; Usadel, B.; et al. Insights into cell wall structure of Sida hermaphrodita and its influence on recalcitrance. Carbohydr. Polym. 2017, 168, 94-102. [CrossRef]

18. Van Soest, P.J.; Robertson, J.B.; Lewis, B.A. Methods for dietary fiber, neutral detergent fiber, and nonstarch polysaccharides in relation to animal nutrition. J. Dairy Sci. 1991, 74, 3583-3597. [CrossRef]

19. Patil, P.N.; Gogate, P.R. Degradation of methyl parathion using hydrodynamic cavitation: Effect of operating parameters and intensification using additives. Sep. Purif. Technol. 2012, 95, 172-179. [CrossRef]

20. Barik, A.J.; Gogate, P.R. Degradation of 4-chloro 2-aminophenol using a novel combined process based on hydrodynamic cavitation, UV photolysis and ozone. Ultrason. Sonochem. 2016, 30, 70-78. [CrossRef]

21. Michalska, K.; Miazek, K.; Krzystek, L.; Ledakowicz, S. Influence of pretreatment with Fenton's reagent on biogas production and methane yield from lignocellulosic biomass. Bioresour. Technol. 2012, 119, 72-78. [CrossRef] [PubMed]

22. Krička, T.; Matin, A.; Bilandžija, N.; Jurišić, V.; Antonović, A.; Voća, N.; Grubor, M. Biomass valorisation of Arundo donax L.; Miscanthus $\times$ giganteus and Sida hermaphrodita for biofuel production. Int. Agrophys. 2017, 31, 575-581. [CrossRef]

23. Chen, S.; Wei, L.; Liu, C.; Wen, Z.; Kincaid, R.L.; Harrison, J.H.; Elliot, D.C.; Brown, M.D.; Solana, A.E.; Stevens, D.J. Value-Added Chemicals from Animal Manure; Pacific Northwest National Laboratory: Richlan, WA, USA, 2003; p. 99352.

24. Habashi, N.; Mehrdadi, N.; Mennerich, A.; Alighardashi, A.; Torabian, A. Hydrodynamic cavitation as a novel approach for pretreatment of oily wastewater for anaerobic co-digestion with waste activated sludge. Ultrason. Sonochem. 2016, 31, 362-370. [CrossRef] [PubMed]

25. Mancuso, G.; Langone, M.; Laezza, M.; Andreottola, G. Decolourization of Rhodamine B: A swirling jet-induced cavitation combined with NaOCl. Ultrason. Sonochem. 2016, 32, 18-30. [CrossRef] [PubMed]

26. Jablonowski, N.D.; Kollmann, T.; Nabel, M.; Damm, T.; Kloose, H.; Müller, M.; Bläsing, M.; Seebold, S.; Krafft, S.; Kuperjans, I.; et al. Valorization of Sida (Sida hermaphrodita) biomass for multiple energy proposes. GCB Bioenergy 2016. [CrossRef]

27. Patil, P.P.; Gogate, P.R.; Csoka, L.; Dregelyi-Kiss, A.; Horvath, M. Intensification of biogas production using pretreatment based on hydrodynamic cavitation. Ultrason. Sonochem. 2016, 30, 79-86. [CrossRef]

28. Rusanowska, P.; Zieliński, M.; Dudek, M.R.; Dębowski, M. Mechanical pretreatment of lignocellulosic biomass for methane fermentation in innovative reactor with cage mixing system. J. Ecol. Eng. 2018, 19, 219-224. [CrossRef]

29. Zieliński, M.; Dębowski, M.; Kisielewska, M. Skuteczność wytwarzania biogazu z wybranych gatunków roślin energetycznych w procesie fermentacji metanowej wspomaganej promieniowaniem mikrofalowym. Ochrona Środowiska 2018, 40, 43-48.

(C) 2019 by the authors. Licensee MDPI, Basel, Switzerland. This article is an open access article distributed under the terms and conditions of the Creative Commons Attribution (CC BY) license (http:/ / creativecommons.org/licenses/by/4.0/). 